\title{
REVIEW.
}

\section{BERTHELOT'S CONTRIBUTIONS TO THE HISTORY OF CHEMISTRY.'}

Marcellin Berthelot, Professor of Chemistry in the Collège de France, Perpetual Secretary of the Academy of Sciences, Senator, Minister of Public Instruction, and recently appointed Minister of Foreign Affairs, known to the scientific world by his masterly researches in synthetical chemistry, has added to these honors that of editing the most important and far-reaching documents pertaining to the history of chemistry ever brought to light.

The six handsome quarto volumes published by him between the years 1887 and 1893 , contain the most ancient Greek, Arabic, Syriac, and Latin treatises on alchemy and technical chemistry preserved in the great libraries of the Old World. Besides reproducing the original text of these precious manuscripts, these volumes contain complete translations of many treatises, analyses of the contents of others, and critical studies of their mutual relations, their sources and authorship, as well as erudite essays on the chemical knowledge exhibited in them. The six volumes form two distinct works: three of the volumes bear the title: "Collection des anciens Alchimistes Grecs," and three of them, "La chimie au moyen âge," each volume having, moreover, specific sub-titles more exactly indicating its contents.

Not having seen any adequate review of these works in English, I propose in this article to examine their scope, contents, and manner of treatment, as well as to show some of the more important changes resulting from Berthelot's historical studies. The existence of ancient Greek and Arabian manuscripts had long been known; Reuvens, and later Leemans, of Holland, had published summaries of certain papyri preserved in Leyden, more than forty years before, but in such a fragmentary manner as merely to excite curiosity. Ferdinand Hoefer, the French historian of chemistry, and Herman Kopp, the erudite German, had made partial use of some of the manuscripts, but it remained for Berthelot to collect and compare the diverse copies, to reproduce and translate them for the benefit of students. This he could scarcely have accomplished without the aid of the French Government, both series being "published under the auspices of the Minister of Public Instruction." Government cooperation was brought about through a report made by Berthelot to 1 Read before the Washington Section of the American Chemical Society, March I2, 1896. 
the "comite des travaux historiques et scientifiques," and adopted by them in 1884 . This report directed attention to the existence of Greek alchemical manuscripts and to the utility of their publication, owing to the great light they throw on the history of natural science, the technology of metals and ceramics, and the history of philosophy in the first centuries of the Christian era.

The difficulties of deciphering, transcribing, and editing Greek, Arabic, Syriac and Latin manuscripts were prodigious, and Berthelot was fortunate in securing scholars of eminence to assist in the task. In dealing with the Greek papyri, he was aided by Ch. Em. Ruelle, of the Bibliothèque Sainte Geneviève, Paris, and by André Berthelot, son of the editor; the Arabic scholar, Professor Houdas, and the Syriac linguist, Rubens Duval, also contributed their learning, each in his own sphere.

The "Collection des Alchimistes Grecs," opens with an "Introduction" by Berthelot, which occupies 268 pages ; this forms an important contribution to the history of chemistry, based upon a critical study of the ancient treatises; he agrees with other historians in tracing the birth of alchemical ideas to Egyptians, whence they reached Europe through Greeks.

Certain Greco-Egyptian papyri, preserved in Leyden, are of the greatest interest; several of them treat of magical formulas, incantations, love philtres, dreams, and similar gnostic notions; one of them, known as "Papyrus X," is a treasury of information on metallurgical operations, at so early a period as the third century of the Christian era. It was found in a tomb at Thebes, secured by the Swedish Consul at Alexandria, Anastasi, and presented by him to the Netherlands in 1828 . Berthelot conjectures it is one of the ancient Egyptian books on the preparation of gold and silver, which escaped the destruction ordered by Diocletian in 290; an order issued lest the people using them should grow rich by their art and revolt against the Romans.

This precious document contains one hundred and one chemical and alchemical recipes, followed by ten paragraphs taken from Dioscorides. The recipes are for making alloys to be used in the manufacture of cups, vases, images, and other objects of the goldsmith's art, also processes for soldering metals and superficially coloring them, besides formulas for making gold and silver inks. The text is full of grammatical errors and ignorant spellings, which show the writing to have been the work of an uneducated artisan; the recipes are not arranged in order, several appear in duplicate; they exhibit no indication of chicanery, although some of the methods are unprofitable. The 
whole papyrus, in short, is evilently the memorandum-book of a goldsmith (or silversmith), engaged in attempts to imitate gold and silver for fraudulent purposes. Only one author is cited, "Phimenas," who is probably Pammenes, author of recipes occuring also in other manuscripts. The preparation of asem, an amalgam of copper and tin, plays a prominent part among the recipes for imitating gold. But time forbids a full analysis of this remarkable manuscript; as a result of Berthelot's careful study of this and analogous treatises, he comes to the conclusion that the doctrines of alchemy concerning the transmutation of metals did not originate in the philosophical views of the constitution of matter, as generally supposed, but in the practical experiments of goldsmiths occupied in making fraudulent substitutes for the precious metals. The "Introduction" contains a chapter on the relations between the metals and the planets, of Chaldean origin, and constant occurrence in the early writings, which is illustrated by facsimiles of several manuscript pages. Another chapter is devoted to the figures of apparatus occurring in the treatises of the eleventh to fourteenth centuries; these include water-baths, digestors, aludels, alembics and a great variety of apparatus for distillation.

The sixth chapter of the introduction is divided into twelve sections; these deal with several Greek manuscripts, notably those preserved in the libraries of St. Mark, Venice, the Escurial, the Vatican, Rome, Gotha, and in Munich, appertaining to the eleventh to fourteenth centuries; of these we note only a few features. At the beginning of the MS. of St. Mark is one of the earliest of chemical bibliographies; it gives the title of fifty-two treatises, verily not in modern style, yet quite suggestive; among them are the following: "Emperor Heraclins, eleven chapters on the manufacture of gold." "Justinian, five chapters on the secret art." "Heliodorus, on the divine art." "Theophrastus, verses on this art." "Moses, on the diplosis (doubling) of gold." "Lexicon of the gold maker, in alphabetical order."

This association of names of Emperors of Rome, Greek classical writers and the Hebrew law giver with chemical and alchemical treatises is characteristic of the period at which they were compiled and by no means denotes actual authorship; the names of prominent men were given to the treatises in order to add to the dignity and authority of the writings. This custom prevailed as late as the sixteenth century, and in certain cases to be noted hereafter, gave rise to undeserved honors. An entire group of writings have been ascribed to Democritus, giving rise in Egypt to what may be styled the school of Democritus. A certain Zosinus of Panoplis is credited with a veritable ency- 
clopedia of the sacred art, a work which occupies ninety pages of Berthelot's volume.

The Collection des Alchimistes Grecs comprises no less than I60 different treatises on the science of Hermes. Many of these are fragmentary in the extreme, extending to only six lines, and even less. All are composed in an archaic, enigmatical style, combining in one undecipherable medley, chemical terms of obscure meaning, magical formulas, astrological notions, citations from mythical authors, and mystical allusions to a philosophy long since buried too deep for present resurrection. It is not surprising that commentators early felt the need of lexicons of the sacred art, and such are preserved in these volumes; unfortunately, however, the definitions are no clearer than the words defined; one word was often used for a score of different objects and processes, and a single article was known by a dozen different names. To convey to readers any idea of these extraordinary literary productions by citations, is hardly practicable in the space available, for passages lose much when removed from their original settings. The actual chemical knowledge exhibited in these ancient manuscripts is varied, and yet indefnite, owing to the numerous obscure expressions; the authors were acquainted with a large number of ores, minerals, earthy substances, and saline bodies, as well as vegetable and animal products, but their ignorance of the mineral acids and their important derivatives, limited them to products obtained by aqueous solution, distillation and the action of heat. Of scientifically classified knowledge there is no trace; the alleged opinions of mythical writers are given as authoritative, and information is imparted in the tedious form of dialogues between philosophers, who remind one of the Scotchman's definition of metaphysicians: "Poor bodies discussing things of which they know nothing, in a language neither of them can understand." Many of the writings contain reverent acknowledgements of the Deity and other evidences of piety. There is a good deal of duplication, arising from the introduction into an essay of passages from another, generally without acknowledgement.

Berthelot remarks incidentally that the term Philosophers' Stone does not occur in writings earlier than the seventh century, although the central idea is much more ancient.

Each of the three quarto volumes which constitute Berthelot's "La chimie au moyen âge " bears an independent title; that of the first volume reads: "Essay on the transmission of the knowledge of Antiquity to the Middle Ages; transmission of technology; translations of Arabico-Latin treatises, with a new 
version of the Liber Ignium of Marcus Graecus, and an original edition of the Liber Sacerdotum."

This volume covers the period from the fall of the Roman Empire to the thirteenth century, thus filling the gap between the ancient Greek alchemists and the Latin writers of the later epoch, a period which had been previously unworked or misunderstood. Berthelot finds that the transmission from the earlier to the later era was accomplished by two agencies; first through the Arabians, who succeeded to the literary and scientific wealth of the Greeks. The Arabic treatises, preserved in the Mohammedan libraries of Spain, were translated into Latin and thus became for Western nations the sources of their knowledge in medicine, alchemy, mathematics and philosophy. Some of these translations were collected and printed in the seventeenth century in the works entitled Theatrum chemicum, (5 vols., I6I3-22), and Bibliotheca chemica, of Mangetus, (2 vols., folio, I702), and Berthelot discovered in these Arabico-Latin treatises entire passages from the ancient Greek Alchemists.

The connection between the Greeks and Arabians was not however immediate, but through the Syrians, who were anong the first to translate the philosophy and science of the Greeks into an oriental tongue. These Syraic versions form the subject of the second volume.

A second link between the Greeks and the Latin alchemy was more directly forged, though difficult of recognition; the processes used in industrial arts and metallurgical operations by the Greeks had been adopted by the Latins as early as the time of the Roman Empire, and this chemical technology was preserved through centuries of intellectual degradation to the beginning of the Middle Ages.

The most ancient Latin treatises on chemical technology are the Compositiones adtingenda, dating from the close of the eighth century, and the Mappa clavicula, written before the tenth century. These are collections of recipes for industrial processes analogous to those in the Leyden papyrus, and forming links in a chain that extends from that ancient work through the treatises of the Middle Ages to the modern "Workshop Recipes" and "Mantels Rorets." The full title of the Compositiones ad tingenda is as follows: [Translation.] " Recipes for coloring mosaics, skins and other objects, for gilding iron, for using minerals, for writing in letters of gold, for soldering metals, and other technical documents." The following are some of the subjects treated: The coloring of artificial stones, used in the manufacture of mosaics; the manufacture of stained glass; the dying of skins in purple, green, yellow and reds; the dyeing of 
wood, bone and horn; a list of ores, metals, earths and metallic oxides used in jewelry and in painting; a number of recipes for gilding on glass, wood, skins, garments, and the metals. All these topics are treated in barbarous Latin, bordering on a species of jargon; some were originally written in Greek and copied by ignorant scribes in Latin letters, which shows the influence of Constantinople. In one of the sections on ores, the word "vitriol" occurs for the first time, being the eighth century, and in the correct significance of an impure ferrous sulphate. A very rational grouping of substances occurs in this work, the minerals and earths are by themselves, then follow gums, rosins and other products of plants, and thirdly substances derived from the ocean, such as salt, coral and mollusks yielding purple dye. A certain recipe for writing in letters of gold is practically identical with one in the Papyrus of Leyden.

A formula for making bronze shows the origin of this name, De compositio brandisii, Brindes being a synonym of Brundusium, (Brindisi), a town noted in Pliny's day for its metallic mirrors.

A large part of Compositiones ad tingenda is reproduced in the work entitled Mappe clavicula, of which the earliest known manuscript dates from the tenth century. This latter treatise contains recipes for making gold, for multiplying gold and imitating the precious metal, closely resembling those of the ancient Greek papyri. In this connection cautions are given to conceal the secrets, and an incantation is prescribed to be used during the operation. Exceeding interest attaches to the fact that the use of the hydrostatic balance in analysis of an alloy is clearly described, for this proves that the knowledge of this instrument did not pass through Arabian channels, and possibly came down direct from Archimedes.

The Liber ignium ad comburendos hostes, by Marcus Graecus, is one of the most ancient Latin treatises on Greek fire, dating from the twelfth or thirteenth century, and is probably a translation from an earlier Greek work transmitted through Arabian channels. It deals with instructions for making Greek fire, so called, phosphorescent materials, fire-proofing substances, and the preparation of fuses and petards, composed in part of saltpeter. Greek fire itself, however, dates from the second century, B. C., and phosphorescent stones are named in the much earlier Greek alchemical manuscripts.

Berthelot devotes an interesting chapter to the discovery of alcohol. This product of distillation first appears under the name aqua ardens, and the term alcohol in its present signification does not occur before the middle of the fourteenth century; the 
term spiritus vini is also comparatively modern, and aqua vitae seems to have been applied to alcohol for the first time by Arnald de Villanova, who died in I3I4. The fact that wine yielded an inflammable substance, was, however, already noted by Aristotle, but this body was not isolated. Rhases has been given credit for acquaintance with alcohol, but this is erroneous.

The preparation of alcohol by distilling wine is, however, mentioned in a copy of the Mappeclavicula, written in the twelfth century, and in the Liber ignium of Marcus Graecus.

In attempting to trace to their origin, Latin treatises which claim to be translated from Arabic, Berthelot made the important discovery that they are fraudulent, the Arabic manuscripts having no existence. Thus the chemical works attributed to the Arabian physician Jabir ibn Hayyan (Abu Musa), commonly called Geber, are shown to be fictitious, and the great reverence paid to him as a pioneer in chemistry has been misplaced. The whole history of chemistry has been falsified by giving credit to the Arabians for knowledge which really belonged to a period five hundred years later.

Yet the historical personage Geber, who lived in the ninth century, left many treatises in Arabic, now preserved in Paris and Leyden, and the translation of these occupy roo pages of the third volume; they are very different from the works so widely known as Geber's, which are found in Latin. French, German, and English.

In like manner the current alchemical treatises ascribed to Raymond Lully are shown to be fictitious, yet his works on philosophy in the Provençal language are extant.

The Pseudo-Arabic works in their Latin form contain, however, traces of the ancient Greek alchemical writings, and to endow them with authority the writers referred the text to mythical personages; and as these were cited by later authors who did not doubt their genuineness, the pseudo-treatises acquired undeserved renown. Students of alchemy who have been revelling in the works of Morien, Kalid, Zadith, Mary, and the collection of citations entitled Turba philosophorum, are loth to have their antique idols shattered, but this is the fate of every branch of human knowledge when subjected to the modern methods of searching analysis.

The second volume of "La chimie au moyen âge" has the subtitle: Syriac Alchemy, comprising an introduction, and several treatises of Syriac and Arabic alchemy from the manuscripts in the British Musenm and Cambridge; text and translation."

The existence of Syriac alchemical mantuscripts in the British 
Museum was pointed out to Berthelot by Prof. Richard Gottheil, of Columbia University, New York City. The most important of these. entitled "The Doctrine of Democritus," was translated from Greek between the seventh and ninth centuries. It begins with a charge of self-purification, followed by a key to the symbols used in the manuscript; these signs resemble in part those occurring in the writings of the earlier Greek alchemists. The first section of the "Doctrine" is called "The Preparation of Gold," the second is called "On the Philosophers' Stone," and the succeeding parts contain a collection of recipes, processes with metals, as well as with sulfur, antimony, arsenic, and ores, analogous to the Leyden papyrus and the Mappee clavicula. Rude drawings of apparatus accompany the text. The writer shows acquaintance with a very large number of chemical substances.

The Library of the University of Cambridge possesses a Syriac manuscript, which is a translation of portions of the Greek writings of Zosimus, Democritus, and others. It is similar in character to the preceding.

Volume III of "I a chimie au moyen âge" has the sub-title: "Arabian Alchemy, comprising an historical introduction, the treatises of Crates, el-Habîb, Ostanes and Djâber from manuscripts in Paris and Leyden ; text and translation."

The Arabic treatises here named are the genuine writings, not the fictitious ones known only in Latin. The first Mohammedan writer on alchemy was Khâled ben Yezid ibn Moaouia, Prince Omeyyade, who died in 708 ; he is a historic personage and the reputed teacher of Djâber. Only the titles of his works have come down to us. Djâber, the Geber of the Latins, was, however, the great master of the art and enjoyed the highest reputation throughout the Middle Ages; he is credited with 500 treatises, an Oriental exaggeration. Six of these are here collected and translated. They exhibit evidence of Moslem faith on the part of the author; he shows familiarity with the hydrostatic balance, with many species of minerals (of which an ingenious classification is given), and he discourses on the changes in volume produced by heat and by cold; at the same time he admits using allegorical and obscure language in all his works. There is no reference to the mineral acids, to nitrate of silver and other chemicals that Geber is supposed to have known. Perhaps the most clever passage in his works is the following from the "Book of Mercy:"-

"I saw that persons engaged in attempts to manufacture gold and silver were working ignorantly and by wrong methods; I 
then perceived that they were divided into two categories, the dupers and the duped. I had pity for both of them."

Berthelot's superb volumes comprise more than 2600 pages, and much of the contents defies review. Besides these original documents he has published two works dealing in more popular style with the periods of alchemy and Middle Age chemistry. These are entitled: "Les Origines de 1'Alchimie," (1885), and "Introduction à l'Étude de la Chimie des Anciens et du Moyen Age" (I889); the latter is largely reprinted in the quarto volumes; all are charmingly written, well illustrated, and well indexed.

Berthelot had extraordinary qualifications for the task and enjoyed unrivalled opportunities, and the result is a magnificent contribution to the history of chemistry, of utmost interest to the chemical student as well as to the philosopher.

H. CARRINGTON BOLTON.

\section{BOOKS RECEIVED.}

Bulletin No. 35. The Agricultural Value of Bone-Meal. Hatch Experiment Station of the Massachusetts Agricultural College, Amherst, Mass. December, I895. 24 pp.

Bulletin No. 36. Imported Elm Leaf Beetle, Maple Pseudo-coccus, Abbot Sphinx, San Josè Scale. Hatch Experiment Station of the Massachusetts Agricultura1 College, Amherst, Mass. February, I8g6. 20 pp.

Bulletin No. 6r. Potatoes. Experiments with Fertilizers. Insects and Fungus Pests. Tests of Varieties. Kentucky Agricultural Experiment Station, Lexington, Ky. March, r896. 42 pp.

Bulletin No.62. Strawberries. Kentucky Agricultural Experiment Station, Lexington, Ky. March, 1896. I6 pp.

Bulletin No. 2r. Field Experiments with Wheat. Missouri Agricultural College Experiment Station, Columbia, Mo. April, I893. I6 pp.

Bulletin No. 3I. Spraying Orchards and Vineyards. Missouri Agricultural College Experiment Station, Columbia, Mo: July, I895. 2 I pp.

Water-Supply. By William P. Mason. New York: John Wiley \& Sons. 8vo. viii, 504 pp. I896. Price, $\$ 5.00$.

Bulletin No. 37. Sundry Brief Articles, compiled from "Press Notes" published during the years 1894 and 1895. Texas Agricultural Experiment Station, College Station, Brazos County, Texas. $83 \mathrm{pp}$.

Eighth Annual Report of the Texas Agricultural Experiment Station for the year ${ }^{8} 895$. Texas Agricultural Experiment Station, College Station, Brazos County, Texas. 42 pp.

Bulletin No. 40. Cow Pea. Agricultural Experiment Station, Baton Rouge, La, $30 \mathrm{pp}$. 